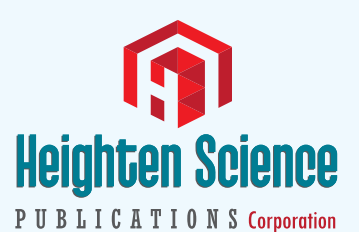

ISSN

2640-284X

\title{
Exercise preserves pancreatic $\beta$-cell mass and function in obese OLETF rats
}

\author{
Jiawei Zhao ${ }^{1}$, Zhihong Yang ${ }^{2}$, Min $\mathrm{He}^{2}$, Qinghua Wang ${ }^{2,3}$ and \\ Renming $\mathrm{Hu}^{2 *}$ \\ 'Department of Pathology, School of Medicine, Wayne State University, Detroit, MI 48201, USA \\ 2Department of Endocrinology, Huashan Hospital, Institute of Endocrinology and Diabetology, \\ Fudan University, Shanghai 200040, China \\ ${ }^{3}$ Division of Endocrinology and Metabolism, Keenan Research Centre for Biomedical Science \\ of St. Michael's Hospital, Departments of Physiology and Medicine, University of Toronto, \\ Toronto, M5B 1W8, Canada
}

\begin{abstract}
*Address for Correspondence: Renming $\mathrm{Hu}$, Department of Endocrinology, Huashan Hospital, Institute of Endocrinology and Diabetology, Fudan University, Shanghai 200040, China, Tel: 86-021-62489999-6591; Email: Renminghu@fudan.edu.cn

Submitted: 26 December 2016

Approved: 18 June 2018

Published: 19 June 2018

Copyright: @ 2018 Zhao J, et al. This is an open access article distributed under the Creative Commons Attribution License, which permits unrestricted use, distribution, and reproduction in any medium, provided the original work is properly cited
\end{abstract}

Keywords: Exercise; Diabetes; Islets; $\beta$-cell mass Abbreviations: LETO: Long-Evans Tokushima Otsuka, OGTT: Oral Glucose Tolerance Test, OLETF: Otsuka Long-Evans Tokushima Fatty

Check for updates

\section{Abstract}

Although exercise has been proposed to be beneficial to type 2 diabetes, its effects on $\beta$-cell function and mass remain unclear. In the present study, the effects of long-term swimming training on the function and mass of $\beta$-cells in diabetic OLETF rats were examined. At 44 weeks of age after developing diabetes, the OLETF rats were divided into two groups: a control group and an exercise group. The exercise group had a daily swimming for 12 weeks. While not found with the control rats, in the obese OLETF rats, the exercise reduced the weight gain which was associated with improved glucose tolerance and elevated circulating insulin levels as determined by the oral glucose tolerance test and insulin ELISA. The exercise improved plasma total cholesterol and triglyceride levels, and also significantly increased the islet $\beta$-cell mass and pancreatic insulin content associated with decreased $\beta$-cell apoptosis and elevated activation of the serine/ threonine kinase, Akt. The present studies suggest that exercise improves diabetes symptoms via enhancement of the $\beta$-cell mass and function through decreasing glucolipotoxicity and reducing $\beta$-cell apoptosis by activating Akt in obese OLETF rats.

\section{Introduction}

A number of studies demonstrated that exercise can prevent or delay the onset of type 2 diabetes [1-3], but whether exercise could improve $\beta$-cell function and mass in people with type 2 diabetes remained unclear.

Otsuka Long-Evans Tokushima Fatty (OLETF) rats were developed as a model of type 2 diabetes, and have a congenital defect of the cholecystokinin-A receptor gene, resulting in hyperphagia and obesity [4]. After an initial period of compensatory hyperinsulinemia, the male OLETF rats usually developed diabetes at 24 weeks of age; all showed similar physical characteristics at 30 weeks of age. However, at approximately 50 weeks, some male OLETF rats showed weight loss, and the others remained obese, similar to that observed in the humans with type 2 diabetes [4]. To investigated whether exercise intervention would improve the function and mass of the $\beta$-cells in diabetic OLETF rats, we examine the effects of long-term swimming training on relevant indicators including 1) body weight, plasma total cholesterol and triglyceride levels, 2) oral glucose tolerance test (OGTT), fasting plasma insulin, pancreatic insulin content, 3 ) $\beta$-cell mass, $\alpha$-cell mass, $\beta / \alpha$ ratio, percentage of apoptotic $\beta$-cells, and 4) $\beta$-cell phospho-Akt expression. 


\section{Materials and Methods}

\section{Animals}

Male OLETF rats were purchased from Otsuka Research Institute (Tokushima, Japan) at 4 weeks of age. The OLETF rats are an established genetic model that resembles human type 2 diabetes. The rats were allowed free access to food and water in a specific pathogen-free environment. All procedures were conducted in accordance with the guidelines of the regulation on animal care approved by the Fudan University Animal Care Committee.

\section{Exercise intervention}

Tokushima At 44 weeks of age, the obese OLETF rats (bodyweight $>500 \mathrm{~g}$ ) were selected and were randomly divided into the two groups: OLETF control group $(n=8)$, and OLETF exercise group $(n=8)$. The exercise group was subjected to swimming for $60 \mathrm{~min}, 5$ days a week for 12 weeks. The control group was left untreated. The second set of controls, the age-matched background Long-Evans Tokushima Otsuka (LETO) rats were used in the parallel experiments: LETO control group $(n=7)$, LETO exercise group $(\mathrm{n}=7)$.

\section{OGTT}

OGTT was performed in rats at 44 and 56 weeks of age. The rats were fasted for 15 $\mathrm{h}$ and gavaged with glucose $(2.0 \mathrm{~g} / \mathrm{kg})$, blood samples were collected from the tail vein at 0, 30, 60 and $120 \mathrm{~min}$; the glucose concentrations were measured using a Freestyle glucose meter (TheraSense, Alameda, USA).

\section{Total cholesterol and triglyceride}

The rats were fasted for $15 \mathrm{~h}$ before blood was sampled from the tail vein. Total cholesterol and triglyceride levels were measured with a Hitachi Autoanalyzer (Type 7070, Hitachi, Tokyo, Japan) as previously described [5].

\section{Insulin RIA}

After the rats were fasted for $15 \mathrm{~h}$, the blood samples were taken and the plasma insulin concentrations were determined using the rat insulin radioimmunoassay kit (Linco Research, Missouri, USA).

\section{Pancreatic insulin content}

Under anesthesia with sodium pentobarbital, a midlaparotomy was performed, and the pancreas was immediately dissected from surrounding tissues, cleared of fat and lymph nodes, weighed, then the whole pancreas was minced with fine scissors in a small beaker with $1.0 \mathrm{ml}$ acidified ethanol, and incubated for $24 \mathrm{~h}$ at $4^{\circ} \mathrm{C}$ to extract insulin from the pancreatic tissue. The extracts were diluted in an insulin assay buffer, and insulin was measured as described [6].

\section{Immunohistochemistry and islet cell mass measurements}

Pancreas was isolated and fixed in $4 \%$ paraformaldehyde for 60 min at $4{ }^{\circ} \mathrm{C}$, rinsed with phosphate-buffered saline (PBS), immersed in $30 \%$ sucrose in PBS at $4^{\circ} \mathrm{C}$ overnight, cut into 12-14 segments and then embedded in optimal cutting temperature (OCT) compound (Mile Laboratories, Elkhart, USA) respectively. The embedded tissues were sectioned at 7 $\mu \mathrm{m}$ in a cryostat. Cryosections from every segment were chosen, and incubated overnight at $4^{\circ} \mathrm{C}$ with primary antibodies (mouse anti-insulin IgG (1:1000), Santa Cruz, California, USA; or mouse anti-glucagon antibody, Sigma, Missouri, USA; or rabbit anti-phosphoAkt (Ser 473) antibody (1:500), Santa Cruz, California, USA). For measurement of the islet cell mass, the samples were then incubated for $1 \mathrm{~h}$ with horseradish peroxidase (HRP)-conjugated sheep anti-mouse IgG (Jackson ImmunoResearch, West Grove, PA, 
USA) and detected with 3,3'-diaminobenzidine tetrahydrochloride (DAB) (Sigma, Missouri, USA); for the determination of $\beta$-cell Akt, this was followed by a $1 \mathrm{~h}$ incubation with the corresponding secondary antibodies conjugated $\mathrm{Cy}-3$ or Cy-2 (1:800, Jackson Immunoresearch Laboratories, West Grove, PA, USA).

$\beta$-cell or $\alpha$-cell mass was measured on a bright field using a fluorescent microscope (Olympus America, NY, USA) connected to a video camera equipped with a color monitor and Image/J software (National Institute of Health, USA). The cross-sectional area occupied by all of the $\beta$-cells or $\alpha$-cells and the cross-sectional area of all pancreatic tissue was quantified. Total $\beta$ - or $\alpha$-cell mass for each pancreas was determined as the product of the total cross-sectional $\beta$ - or $\alpha$-cell area over total tissue area and the weight of the pancreas before fixation as described previously [6].

Quantification of the staining intensity was made by the mean immunofluorescence intensity (MFI) using Image/J software (National Institute of Health, USA) and the total numbers of pixels were then calculated per individual cell. To minimize variations, the tissues were processed simultaneously with identical batches of all solutions from the beginning of tissue harvesting to the end of staining. The background of the image was subtracted from the total number of pixels in the threshold. Typically, $\sim 3000 \beta$-cells from each animal in each group were analyzed.

\section{Detection of $\beta$-cell apoptosis}

$\beta$-cell apoptosis was determined using a previously reported protocol with a slight modification. Briefly, the insulin-stained cryosections were co-stained with Hoechst $33342(2 \mathrm{mg} / \mathrm{ml}$, Sigma, Missouri, USA) for $5 \mathrm{~min}$ at room temperature. Apoptotic cells were identified by the characteristic of condensed or fragmented nuclei of cells examined under a fluorescent microscope [7]. The results were expressed as the percentage of apoptotic over total $\beta$-cell nuclei.

\section{Statistical analysis}

An unpaired Student's T-test was used for statistical analysis. A $P$ value of $<0.05$ was considered significant. All data are expressed as mean \pm SE.

\section{Results}

\section{Body weight and total cholesterol and triglyceride}

As shown in table 1 , at 56 weeks of age, body weight in the obese OLETF exercise group rats was reduced by $10.8 \%$ when compared to those of obese OLETF control rats $(\mathrm{p}<0.05, \mathrm{n}=8)$. In the control LETO rats, however, while lower body weight was observed in the exercised group (by $4.5 \%$ ) it was not statistically significant.

At 56 weeks of age, the circulating fasting insulin levels were significantly elevated in the obese OLETF exercise group compared to those of OLETF control rats (exercise vs. non-exercise $=1.33 \pm 0.12$ vs. $0.81 \pm 0.05, \mathrm{p}<0.05, \mathrm{n}=8$ ). The total cholesterol and triglyceride were found to be significantly reduced in the obese OLETF exercise rats, compared to the obese OLETF control group ( $p<0.05, n=8)$. However, the total cholesterol and triglyceride in the in two groups of LETO rats were not significantly changed by the exercise $(\mathrm{p}>0.05, \mathrm{n}=7)$.

OGTT After 12 weeks of exercise, at the age of 56 weeks, the obese OLETF rats

Table 1: Body weight, fasting plasma insulin, triglycerides, and total cholesterol at $56 \mathrm{wk}$

\begin{tabular}{|c|c|c|c|c|}
\hline & \multicolumn{2}{|r|}{ LETO } & \multicolumn{2}{|c|}{ OLETF } \\
\hline & control group & exercise group & control group & exercise group \\
\hline $\mathbf{n}$ & 7 & 7 & 8 & 8 \\
\hline Body weight (g) & $564.8 \pm 25.4$ & $529.5 \pm 9.8$ & $630.0 \pm 36.0$ & $561.7 \pm 32.2 \dagger$ \\
\hline Fasting plasma insulin (ng/ml) & $2.54 \pm 0.87$ & $2.47 \pm 0.65$ & $0.81 \pm 0.05$ & $1.33 \pm 0.12 \dagger$ \\
\hline Triglycerides (mmol/L) & $0.44 \pm 0.05$ & $0.61 \pm 0.04$ & $1.64 \pm 0.13$ & $0.83 \pm 0.06 t$ \\
\hline Total cholesterol (mmol/L) & $2.25 \pm 0.21$ & $2.15 \pm 0.02$ & $4.31 \pm 0.56$ & $2.75 \pm 0.63 \dagger$ \\
\hline
\end{tabular}


exhibited improved glucose tolerance compared to the unexercised OLETF rats (Figure 1A). When expressed as area under the curve (AUC), the improvement in the glucose tolerance is statistically significant (Figure 1B). The 12 weeks of exercise did not significantly alter the glucose tolerance in the control LETO rats (Figures 1C,D).

\section{Islet mass and pancreatic insulin content}

At 56 weeks of age, the pancreatic mass was not significantly different between the exercised and non-exercised OLETF rats; there was no significant difference found between OLETF and LETO rats (Table 2). At 56 weeks of age, the OLETF rats displayed reduced pancreatic insulin content (by 70\%, p<0.05) in comparison with those of age-matched LETO rats. However, the exercise led to a more than 2-fold increase in pancreatic insulin content in the obese OLETF rats (Table 2, exercise vs. non-exercise $=0.36 \pm 0.06$ vs. $0.17 \pm 0.03, \mathrm{p}<0.05, \mathrm{n}=5$ ).

The representative islet architectures from each of the four groups of rats as evaluated by the insulin and glucagon staining are shown in figure 2. At 56 weeks of age, the islets from the LETO control rats are shown as oval, with a clear mantle of $\alpha$-cells and a core of $\beta$-cells and therefore maintained normal islet architecture (Figures $2 \mathrm{~A}, \mathrm{~B})$. No significant difference in $\beta$-cell mass was found between LETO exercise and control rats ( $>0.05, n=4$, table 2$)$. On the contrary, at the same age, the islets from OLETF control rats were degranulated with reduced islet $\beta$-cells and $\alpha$-cells scattered throughout the islets (Figure 2C,G). However, the obese OLETF exercise group rats (Figure $2 \mathrm{D}, \mathrm{H}$ ) reserved a better islet architecture with more $\beta$-cells in the islets compared to those from the obese OLETF control group (Figure 2C,G). The $\beta$-cell mass in the obese OLETF exercise group of rats was significantly larger than those of the obese OLETF non-exercise rats (exercise vs. non-exercise $=12.25 \pm 1.85$ vs. $7.16 \pm 0.71$, $\mathrm{p}<0.05, \mathrm{n}=5$, table 2 ). While the $\alpha$-cell mass was not found to be significantly altered

A

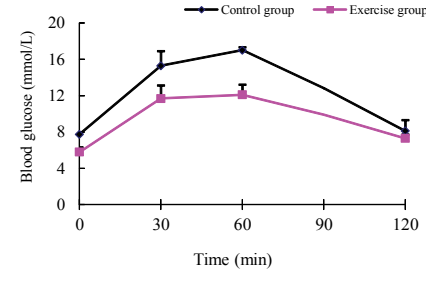

$\mathrm{C}$

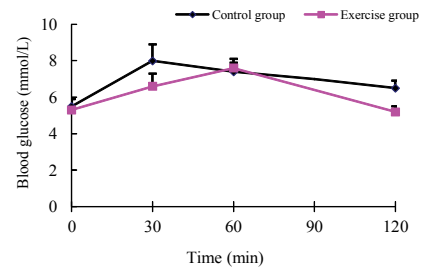

B

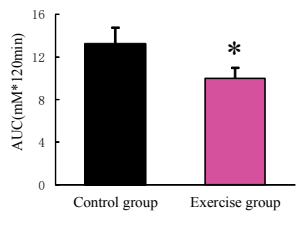

OLETF

$\mathrm{D}$

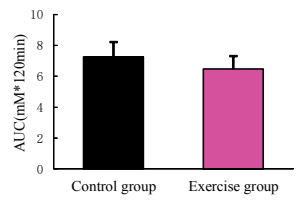

LETO

Figure 1:

Table 2: Pancreatic mass, insulin content, $\beta$-cell and $\alpha$-cell mass, $\beta / \alpha$ ratio, and percentage of apoptotic $\beta$-cells at 56 wk.

\begin{tabular}{|c|c|c|c|c|}
\hline & \multicolumn{2}{|c|}{ LETO } & \multicolumn{2}{c|}{ OLETF } \\
\cline { 2 - 5 } & control group & exercise group & control group & exercise group \\
\hline $\mathbf{n}$ & 4 & 4 & 5 & 5 \\
\hline Pancreas (g) & $1.72 \pm 0.18$ & $2.22 \pm 0.10$ & $1.71 \pm 0.21$ & $2.04 \pm 0.13$ \\
\hline Pancreatic insulin content (ug/mg protein) & $0.48 \pm 0.09$ & $0.51 \pm 0.08$ & $0.17 \pm 0.03$ & $0.36 \pm 0.06^{\star}$ \\
\hline$\beta$-cell mass (mg) & $25.39 \pm 6.04$ & $27.24 \pm 5.77$ & $7.16 \pm 0.71$ & $12.25 \pm 1.85^{\star}$ \\
\hline a-cell mass (mg) & $5.97 \pm 1.04$ & $6.22 \pm 1.13$ & $6.11 \pm 0.73$ & $5.28 \pm 0.65$ \\
\hline$\beta /$ a ratio & $4.17 \pm 0.77$ & $4.35 \pm 0.97$ & $1.18 \pm 0.11$ & $2.33 \pm 0.21^{\star}$ \\
\hline Percentage of apoptotic $\beta$-cells (\%) & $0.39 \pm 0.07$ & $0.41 \pm 0.05$ & $5.95 \pm 0.45$ & $2.29 \pm 0.10^{\star}$ \\
\hline
\end{tabular}

Data are mean \pm SE. $* \mathrm{P}<0.05$ for OLETF exercise vs. OLETF control group. 


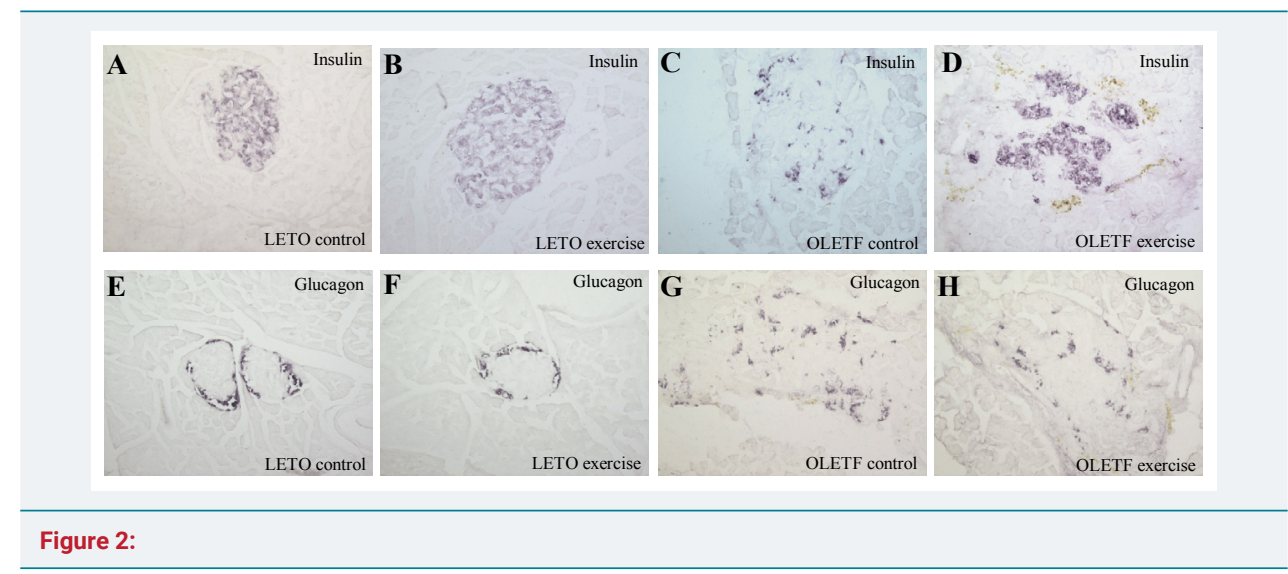

by the exercise, the $\beta$-cell $/ \alpha$-cell ratio in the obese OLETF exercise group was found to be significantly increased by 2 -fold versus the control group ( $2.33 \pm 0.21$ vs. $1.18 \pm 0.11$, $\mathrm{p}<0.05, \mathrm{n}=5$ ) (Table 2).

\section{$\beta$-cells apoptosis}

As shown in table 2 , all OLETF rats displayed significantly increased $\beta$-cell apoptosis, however, the exercise significantly reduced the apoptotic rate in the obese OLETF rats (exercise vs. non- exercise $=2.29 \pm 0.10$ vs. $5.95 \pm 0.45, \mathrm{p}<0.05, \mathrm{n}=5$ ). The $\beta$-cell apoptosis rate was not significantly altered by exercise in the LETO control groups.

\section{Phospho-Akt protein expression}

The MFI from phospho-Akt antibody-stained pancreatic sections from the obese OLETF exercise group vs. obese OLETF control group were $67.3 \pm 4.5$ vs. $25.6 \pm 3.2$ ( $P<$ $0.05, \mathrm{n}=5$ ) (Figure 3 ) that suggesting that the exercise enhanced $\beta$-cell Akt signaling in the $\beta$-cells. Interestingly, the exercise did not elevate $\beta$-cell phospho-Akt expression in LETO rats.

\section{Discussion}

Obesity seems to be a primary risk factor for the development of insulin resistance and diabetes. Weight loss is associated with a decrease in insulin resistance $[8,9]$, and

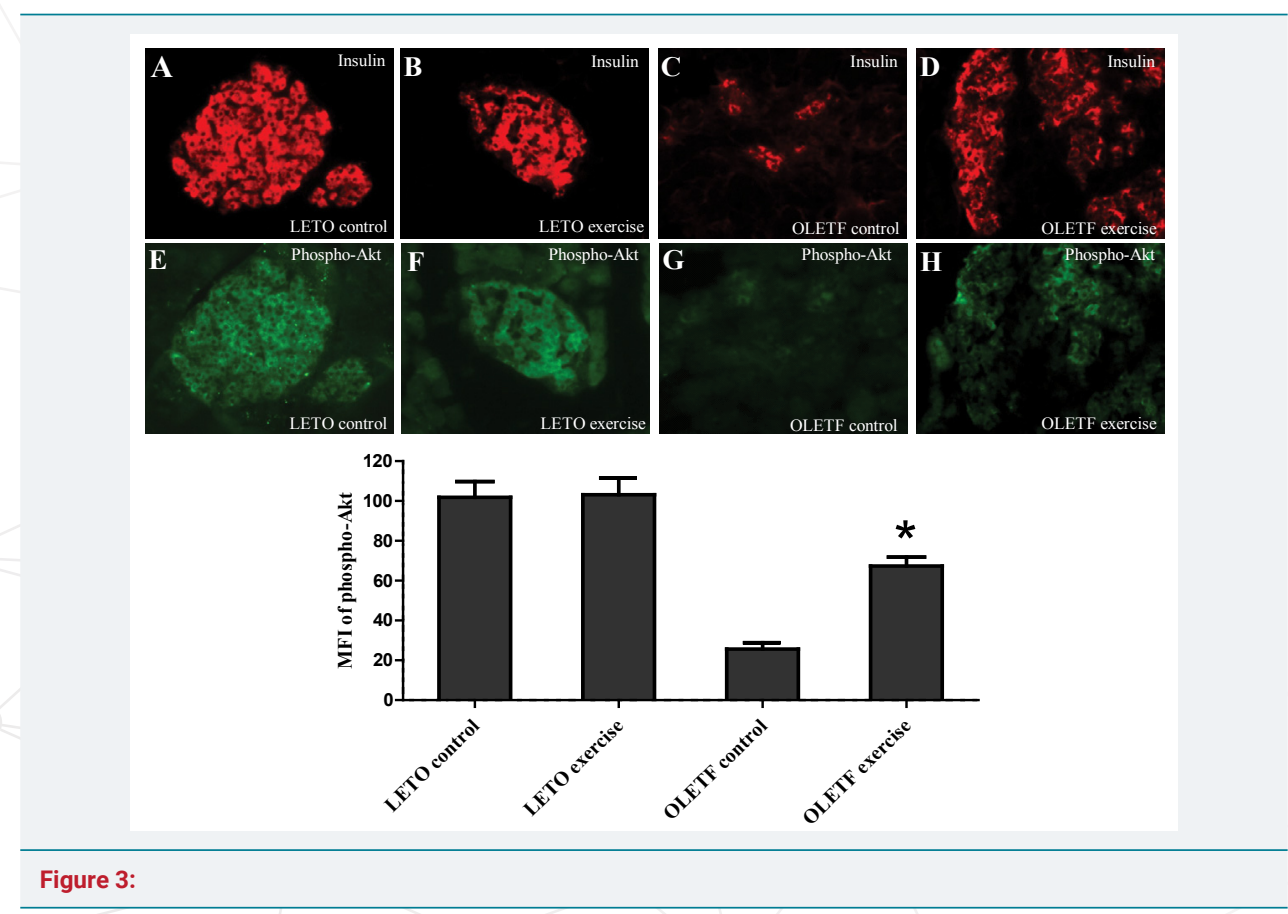


reduces the risk of developing diabetes [1,10]. Obesity is attributable to imbalances between energy intake and energy expenditure and findings from both cross-sectional and prospective studies suggest that decreased total energy expenditure is the primary determinant of increasing weight and obesity $[11,12]$. In the present study, regular swimming training lead to significant loss of body weight in the obese diabetic OLETF rats that might be through increasing energy expenditure.

Type 2 diabetes is a metabolic disease characterized by abnormal glucose and fat metabolism. In this study, the exercise significantly altered the glycemic response and thus improved the glucose tolerance in the obese OLETF rats. The improved glucose tolerance occurs primarily because of an enhancement of islet $\beta$-cell competence as a result of exercise, since the circulating plasma insulin levels as well as the pancreatic insulin were significantly increased in the obese OLETF rats after exercise. It is possible, however, that the improved glucose tolerance might also be the result of an improved peripheral insulin sensitivity because of that exercise increases limb blood flow, enhances glucose transport in the insulin responsiveness tissues via augmenting insulin signaling [13], enhances GLUT-4 expression and facilitates its intracellular translocation [14]. Our results also showed that exercise significantly reduced the blood lipid profile in the obese OLETF rats which is in good agreement with the previous findings that exercise could promote the muscles to burn more fat by activation of a number of enzymes which are necessary for lipid catabolism in the skeletal muscles [15]; meanwhile, exercise could also ameliorate release and enhance the clearance of free fatty acid [16].

In the advanced stages of type 2 diabetes (i.e. at 56 wks of age), the islets were found to be degranulated with reduced $\beta$-cell mass which accounted for the decreased pancreatic insulin content, and impaired glucose tolerance in the obese diabetic OLETF rats. The inadequate $\beta$-cell mass is thus an important contributor to the $\beta$-cell dysfunction and subsequent to the progression of type 2 diabetes [17].

It is conceivable that the obese diabetic OLETF rats, after 12 weeks of swimming exercise, displayed ameliorated diabetes symptoms, improved glucose tolerance and elevated circulating fasting insulin levels, which could be attributed to the enhanced $\beta$-cell mass and increased pancreatic insulin content.

The maintenance of $\beta$-cell mass is a dynamic process, undergoing both increases and decreases to keep glycaemia within a narrow physiological range [18]. The $\beta$-cell apoptosis is known to be a major cause of reduction of $\beta$-cell mass in animal models of type 2 diabetes [19], and humans with type 2 diabetes [20]. It has been previously demonstrated that the glucolipotoxicity is an important factor that causes $\beta$-cell death $[21,22]$. Our present study shows that the 12 weeks swimming exercise increased $\beta$-cell mass in the OLETF rats which is consistent with the observations that the exercise significantly reduced the $\beta$-cell apoptosis in these rats. In addition, our study shows that after 12 weeks swimming exercise, the total triglycerides and cholesterol levels were found to be significantly decreased in the OLETF rats suggesting that declined glucolipotoxicity might have, at least in part, contributed to the enhancement of the $\beta$-cell mass via reduction of the rate of $\beta$-cell apoptosis. Further to this, we believe that the elevated Akt activation found in the exercised OLETF rats is also critical to the process of enhancing $\beta$-cell mass during the exercise.

Reduction of Akt activity in the peripheral tissues had been observed in insulin resistance and type 2 diabetes [23,24]. Previous studies suggested that Akt is important in promoting $\beta$-cell growth and inhibiting $\beta$-cell apoptosis in vitro $[25,26]$, and in an in vivo type 2 diabetes animal mode [6]. It is thus likely that Akt signaling is critical to the regulation of $\beta$-cell mass and function [27], and impairment of Akt signaling in the $\beta$-cells might contribute to $\beta$-cell loss in the pathogenesis of type 2 diabetes [22]. In our 
previous study, we showed that impaired $\beta$-cell insulin signaling contributes the onset of overt diabetes in OLETF rats [28], it is required for further investigation whether the elevated Akt activity in the OLETF rats is involved in the improvement of $\beta$-cell insulin signaling by decrease of glucolipotoxicity via exercise.

\section{Conclusion}

The present study showed that in diabetic OLETF rats, the glucose tolerance is significantly improved after 12 weeks swimming exercise which was associated with enhanced $\beta$-cell mass, increased pancreatic content and circulating insulin levels. These findings suggest that exercise has a protective effect in type 2 diabetes by decreasing glucolipotoxicity and enhancing $\beta$-cell Akt activity. Exercise training may be an effective therapy for obese patients with type 2 diabetes.

\section{Acknowledgements}

This work was supported by a grant from the National Natural Science Foundation of China (to RM Hu, Key Program, grant\# 30230380), and by a grant from the Canadian Institute for Health Research (to Q Wang, MOP-79534). We thank Dr. Paul Doherty (St. Michael's Hospital, Toronto) for critical reading of the manuscript.

\section{References}

1. Manson JE, Rimm EB, Stampfer MJ, Colditz GA, Willett WC, et al. Physical activity and incidence of non-insulin-dependent diabetes mellitus in women. Lancet. 1991; 338: 774-778. Ref.: https://tinyurl.com/y8dz94fg

2. Pan XR, Li GW, Hu YH, Wang JX, Yang WY, et al. Effects of diet and exercise in preventing NIDDM in people with impaired glucose tolerance. The Da Qing IGT and Diabetes Study. Diabetes Care. 1997; 20:537- 544. Ref.: https://tinyurl.com/y9657hcr

3. Pold R, Jensen LS, Jessen N, Buhl ES, Schmitz O, et al. Long-term AICAR administration and exercise prevents diabetes in ZDF rats. Diabetes. 2005; 54: 928-934. Ref.: https://tinyurl.com/yad8kvje

4. Mizuno A, Noma Y, Kuwajima M, Murakami T, Zhu M, et al. Changes in islet capillary angioarchitecture coincide with impaired B-cell function but not with insulin resistance in male Otsuka-Long-EvansTokushima fatty rats: dimorphism of the diabetic phenotype at an advanced age. Metabolism. 1999; 48:477- 483. Ref.: https://tinyurl.com/y9ldt4of

5. Tomoyuki Nishimoto, Yuichiro Amano, Ryuichi Tozawa, Eiichiro Ishikawa, Yoshimi Imura, et al. Lipidlowering properties of TAK-475, a squalene synthase inhibitor, in vivo and in vitro. $\mathrm{Br} \mathrm{J}$ Pharmacol. 2003; 139: 911- 918. Ref.: https://tinyurl.com/yd7w9u2m

6. Wang Q, Brubaker PL. Glucagon-like peptide-1 treatment delays the onset of diabetes in 8 week-old db/db mice. Diabetologia. 2002; 45: 1263-1273. Ref.: https://tinyurl.com/ydyxthup

7. Scaglia L, Cahill CJ, Finegood DT, Bonner-Weir S. Apoptosis participates in the remodeling of the endocrine pancreas in the neonatal rat. Endocrinology. 1997; 138: 1736-1741. Ref.: https://tinyurl.com/ybpyqusq

8. Beck-Nielsen $\mathrm{H}$, Pedersen $\mathrm{O}$, Lindskov $\mathrm{HO}$. Normalization of the insulin sensitivity and the cellular insulin binding during treatment of obese diabetics for one year. Acta Endocrinol (Copenh). 1979; 90: 103-112. Ref.: https://tinyurl.com/y74zrm7u

9. Freidenberg GR, Reichart D, Olefsky JM, Henry RR. Reversibility of defective adipocyte insulin receptor kinase activity in non-insulin-dependent diabetes mellitus. Effect of weight loss. J Clin Invest. 1988; 82: 1398-1406. Ref.: https://tinyurl.com/yb8kyl4z

10. Manson JE, Nathan DM, Krolewski AS, Stampfer MJ, Willett WC, et al. A prospective study of exercise and incidence of diabetes among US male physicians. JAMA. 1992; 268: 63-67. Ref.: https://tinyurl.com/y9ztz3as

11. Crawford DA, Jeffery RW, French SA. Television viewing, physical inactivity and obesity. Int J Obes Relat Metab Disord. 1999; 23: 437-440. Ref.: https://tinyurl.com/yddx4l6q

12. Martínez-González MA, Martínez JA, Hu FB, Gibney MJ, Kearney J, et al. Physical inactivity, sedentary lifestyle and obesity in the European Union. Int J Obes Relat Metab Disord. 1999; 23: 1192-1201. Ref.: https://tinyurl.com/ybwsdbqq 
13. Youngren JF, Keen S, Kulp JL, Tanner CJ, Houmard JA, et al. Enhanced muscle insulin receptor autophosphorylation with short-term aerobic exercise training. Am J Physiol Endocrinol Metab. 2001; 280: 528-533. Ref.: https://tinyurl.com/ydf5dmb4

14. Holten MK, Zacho M, Gaster M, Juel C, Wojtaszewski JF, et al. Strength training increases insulinmediated glucose uptake, GLUT4 content, and insulin signaling in skeletal muscle in patients with type 2 diabetes. Diabetes. 2004; 53: 294-305. Ref.: https://tinyurl.com/y9srdo59

15. Saltin B, Helge JW. Metabolic capacity of skeletal muscles and health. Ugeskr Laeger. 2000; 162 2159-2164. Ref.: https://tinyurl.com/y9hrawkw

16. Ivy JL, Zderic TW, Fogt DL. Prevention and treatment of non-insulin-dependent diabetes mellitus. Exerc Sport Sci Rev. 1999; 27: 1-35. Ref.: https://tinyurl.com/ybnh39mu

17. Donath MY, Ehses JA, Maedler K, Schumann DM, Ellingsgaard $\mathrm{H}$, et al. Mechanisms of beta-cell death in type 2 diabetes. Diabetes. 2005; 2: 108-113. Ref.: https://tinyurl.com/y7jdlfgo

18. Bonner-Weir S. Life and death of the pancreatic beta cells. Trends Endocrinol Metab. 2000; 11: 375378. Ref.: https://tinyurl.com/ybfhnrtp

19. Pick A, Clark J, Kubstrup C, Levisetti M, Pugh W, et al. Role of apoptosis in failure of beta-cell mass compensation for insulin resistance and beta-cell defects in the male Zucker diabetic fatty rat. Diabetes. 1998; 47: 358- 364. Ref.: https://tinyurl.com/y9w6edoh

20. Butler AE, Janson J, Bonner-Weir S, Ritzel R, Rizza RA, et al. Beta-cell deficit and increased beta-cell apoptosis in humans with type 2 diabetes. Diabetes. 2003; 52: 102-110. Ref.: https://tinyurl.com/y75wps4e

21. El-Assaad W, Buteau J, Peyot ML, Nolan C, Roduit R, et al. Saturated fatty acids synergize with elevated glucose to cause pancreatic beta-cell death. Endocrinology. 2003; 144: 4154-4163. Ref.: https://tinyurl.com/y7cyyt4t

22. Dickson LM, Rhodes CJ. Pancreatic beta-cell growth and survival in the onset of type 2 diabetes: a role for protein kinase B in the Akt? Am J Physiol Endocrinol Metab. 2004; 287: 192-198. Ref.: https://tinyurl.com/y7m4gn56

23. Qi J, Yang B, Ren C, Fu J, Zhang J. Swimming Exercise Alleviated Insulin Resistance by Regulating Tripartite Motif Family Protein 72 Expression and AKT Signal Pathway in Sprague-Dawley Rats Fed with High-Fat Diet. J Diabetes Res. 2016; Ref.: https://tinyurl.com/ybs47p62

24. White MF. IRS proteins and the common path to diabetes. Am J Physiol Endocrinol Metab. 2002 283: 413-422. Ref.: https://tinyurl.com/y94ugynx

25. Wang Q, Li L, Xu E, Wong V, Rhodes C, et al. Glucagon-like peptide-1 regulates proliferation and apoptosis via activation of protein kinase B in pancreatic INS-1 beta cells. Diabetologia. 2004; 47 478-487. Ref.: https://tinyurl.com/ybefeuxv

26. Wrede CE, Dickson LM, Lingohr MK, Briaud I, Rhodes CJ. Protein kinase B/Akt prevents fatty acidinduced apoptosis in pancreatic beta-cells (INS-1). J Biol Chem. 2002; 277: 49676-49684. Ref.: https://tinyurl.com/ydbaaach

27. Elghazi L, Balcazar N, Bernal-Mizrachi E. Emerging role of protein kinase B/Akt signaling in pancreatic beta-cell mass and function. Int J Biochem Cell Biol. 2006; 38:157-163. Ref.: https://tinyurl.com/yb84boxp

28. Zhao J, Zhang $\mathrm{N}, \mathrm{He} \mathrm{M}$, Yang Z, Tong $\mathrm{W}$, et al. Increased $\beta$-cell apoptosis and impaired insulin signaling pathway contributes to the onset of diabetes in OLETF rats. Cell Physiol Biochem. 2008 21: 445-454. Ref.: https://tinyurl.com/yb9bbj9d 